\title{
Bacterioplankton viability in Antarctic waters as affected by solar ultraviolet radiation
}

\author{
E. Walter Helbling ${ }^{1, *}$, Emilio R. Marguet ${ }^{2}$, Virginia E. Villafañe ${ }^{1}$, \\ Osmund Holm-Hansen ${ }^{1}$
}

\author{
${ }^{1}$ Polar Research Program, Scripps Institution of Oceanography, University of California at San Diego, La Jolla, \\ California 92093-0202, USA \\ ${ }^{2}$ Cátedra de Biología Celular y Molecular, Facultad de Ciencias Naturales, Universidad Nacional de la Patagonia, \\ 9100 Trelew, Chubut, Argentina
}

\begin{abstract}
The effect of solar ultraviolet radiation (UVR) on viability of natural bacterioplankton assemblages from Antarctic waters, as well as on 2 cultures of isolated bacterial strains (Acinetobacter $\mathrm{sp}$. and Bacillus sp.). was determined by both in situ and temperature-controlled incubator experiments. When natural assemblages were incubated in situ at $0.5 \mathrm{~m}$ depth, the mean percentage survival fractions (of the bacteria forming colonies on agar) were $13 \%$ when the sample was exposed to all UVR, $27 \%$ when UV-B radiation was eliminated with a prefilter, and $85 \%$ when all UVR was excluded. The magnitude of UVR-induced inhibition decreased with depth so that there was no significant inhibition at $9.5 \mathrm{~m}$. There was very little effect of photosynthetically available radiation (PAR), even at $0.5 \mathrm{~m}$ depth. The loss of viability due to UVR or PAR was much greater for the 2 isolated strains than for the natural bacterial assemblages. Exposure of the Bacillus sp. to incident PAR, PAR + UV-A, and PAR + UV-A + UV-B resulted in survival values of $9,0.4$, and $0.1 \%$, respectively; when irradiance to the sample was reduced to about $3 \%$ of the incident value, the corresponding values were 80,50 , and $24 \%$, respectively. With Acinetobacter sp., the corresponding values were 60, 13, and $1.5 \%$ with direct exposure to solar radiation, while at $12 \%$ of incident radiation no inhibition by either UVR or PAR could be detected. The SOS-repair system could be induced in both bacterial strains studied with the result that the loss in viability due to UVR radiation was much reduced, but both strains still showed some loss of viability when compared to the control samples.
\end{abstract}

KEY WORDS: Bacterioplankton - Ultraviolet radiation · Antarctica · Viability

\section{INTRODUCTION}

It is generally recognized that bacterioplankton biomass in the euphotic zone of marine waters usually amounts to 10 to $50 \%$ of the phytoplankton biomass, and that a large fraction of the primary production is either assimilated or respired by the bacterial assemblages (Cho \& Azam 1990). Since the progressive deepening of the seasonal ozone hole in the Antarctic during the $1980 \mathrm{~s}$, much effort has been devoted to studying the impact of ultraviolet-B (UV-B, 280 to $320 \mathrm{~nm}$ ) and UV-A (320 to $400 \mathrm{~nm}$ ) radiation on phyto-

•E-mail: whelbling@ucsd.edu plankton (see Weiler \& Penhale 1994). Most of the studies with phytoplankton have shown that UV-A radiation is responsible for a larger decrease in photosynthetic rates than UV-B radiation (Helbling et al. 1992. Smith et al. 1992, Holm-Hansen et al. 1993). Much of the inhibition of photosynthesis in phytoplankton is thought to be due to structural changes and oxidation of pigments associated with the absorption and transfer of energy in photosynthesis (Young et al. 1993). As bacterioplankton have very different cellular absorption spectra as compared to phytoplankton, the relative impacts of UV-A and UV-B radiation on metabolic processes in bacterioplankton cannot be assumed to be similar to phytoplankton, but must be determined by direct experimentation. 
In this paper we report the effect of solar UVR (UV radiation) on the viability of natural Antarctic bacterioplankton assemblages, as well as on 2 isolated species (Acinetobacter sp. and Bacillus sp.) when exposed to various photoregimes in situ or in temperature-controlled incuba:ors. Also, the importance of the SOSrepair system, a regulatory system that increases the expression of genes for repair of DNA damage, was studied for the 2 isolated bacterial species.

\section{MATERIALS AND METHODS}

Our work was performed at Palmer Station, Antarctica $\left(64.7^{\circ} \mathrm{S}, 64.1^{\circ} \mathrm{W}\right)$ during November-December 1993. Natural bacterioplankton assemblages were obtained from surface water samples taken with a sterile polycarbonate bottle (1 l) at a station in Arthur Harbor, Antarctica, from the bow of a slowly moving Zodiac boat. These samples were either used directly for the in situ experiments or used to isolate individual bacterial strains. Isolation was done by diluting 1 volume of the sample with 2 volumes of isotonic marine broth (Difco 0791-01-2). After 12 h at $4^{\circ} \mathrm{C}$, subsamples were streaked onto either nutrient marine agar (Difco 0142$01-8 ; 1.5 \%$ ) or Schaedler agar (Difco 0534-17-6; 1.5\%) in petri dishes. After incubation for $48 \mathrm{~h}$ at $4^{\circ} \mathrm{C}$, selected colonies were isolated and identified following the methodology described by Austin (1982). Two isolates (a Gram-negative Acinetobacter sp. and a Gram-positive Bacillus sp.) were selected for experimental use and were maintained on nutrient marine agar. Before use in any experiment, an inoculum was transferred to marine broth and the suspension incubated for 18 to $24 \mathrm{~h}$ in order to reach the exponential growth phase. Aliquots $(0.5 \mathrm{ml})$ of the suspension were then transferred to $50 \mathrm{ml}$ quartz tubes (Teflon-lined screw caps) containing $50 \mathrm{ml}$ of sterile seawater to reach a concentration of $10^{5}$ to $10^{6}$ cells $\mathrm{ml}^{-1}$. When using natural bacterial assemblages in experiments, the $50 \mathrm{ml}$ quartz tubes were filled directly with the water sample.

The experimental samples were exposed to 3 different spectral irradiation regimes: (1) samples in quartz tubes, received UV-B + UV-A + photosynthetically available radiation (PAR, 400 to $700 \mathrm{~nm}$ ); (2) samples in tubes Covered with a Mylar filter, received UV-A + PAR; (3) samples in tubes covered with a Plexiglas (UF3) filter, received only PAR. The Mylar and Plexiglas filters have $50 \%$ transmission at 323 and $400 \mathrm{~nm}$, respectively.

Two types of incubations were performed to assess the effects of solar radiation on viability of the bacterial suspensions, as influenced by the spectral irradiance or the fluence of the radiation to which the sample was exposed. (1) For in situ incubations, 6 of the $50 \mathrm{ml}$ tubes (duplicates of the 3 different spectral irradiance regimes) were placed on black-anodized aluminum frames, which were then placed at various depths in the water column between 0.5 to $17 \mathrm{~m}$. (2) The tubes with samples of the 2 isolated bacterial strains were incubated in an outdoor water bath which was exposed to direct sunlight and cooled with flowing seawater. All incubator experiments also included dark control samples which were covered with aluminum foil. In some of these experiments, incident solar radiation was attenuated with various layers of neutral density screening so that irradiance received by the samples varied from 100 to $3 \%$ of the incident radiation. Other experiments were designed to assess the importance of the SOS-repair system (Little \& Mount 1982, Sancar \& Sancar 1988). In these experiments, the samples were incubated with nalidixic acid, which interferes with DNA replication and thus induces the SOS-repair system (Piddock \& Walters 1992), at a concentration of $50 \%$ of the minimal inhibitory concentration (MIC) for $1 \mathrm{~h}$ preceding the experiment. The MIC for each of the 2 bacterial strains had been determined in preliminary tests; the concentrations used for the exposure experiments were $10 \mathrm{mg} \mathrm{l}^{-1}$ for Bacillus sp. and $20 \mathrm{mg} \mathrm{l}^{-1}$ for Acinetobacter $\mathrm{sp}$

Viability of the bacteria was determined by counting colonies on plates at the beginning of each experiment and after the incubations. Plates of Schaedler agar were inoculated with $50 \mu \mathrm{l}$ of each dilution of the original samples (final dilutions of $10^{-3}, 10^{-4}$, and $10^{-5}$ ) and incubated for $48 \mathrm{~h}$. Counting was done on the plates which had between 50 and 250 colony-forming units (CFU).

Incident solar radiation was recorded once per minute, using a spectroradiometer (PUV-510, Biospherical Instruments, Inc.) that measures UVR at 4 wavelengths $(305,320,340$, and $380 \mathrm{~nm})$ and also PAR. The underwater attenuation of solar radiation was measured with a PUV-500 spectroradiometer (Biospherical Instruments, Inc.) that has the same 5 channels mentioned above, in addition to sensors for depth and temperature.

\section{RESULTS}

Data from in situ incubations performed with natural bacteria assemblages, as well as with the strains of Acinetobacter sp. and Bacillus sp., are shown in Fig. 1 The viability of natural bacterial assemblages (Fig. 1A) was significantly decreased by UVR, but not by PAR. The survival fraction of samples incubated at $0.5 \mathrm{~m}$ in quartz tubes without any covering filter was 0.13 (i.e. the percentage of viable cells was $13 \%$ as compared to dark control samples). When UV-B was excluded from the sample, the survival fraction increased to $27 \%$. The magnitude of this UVR-induced inhibition decreased 

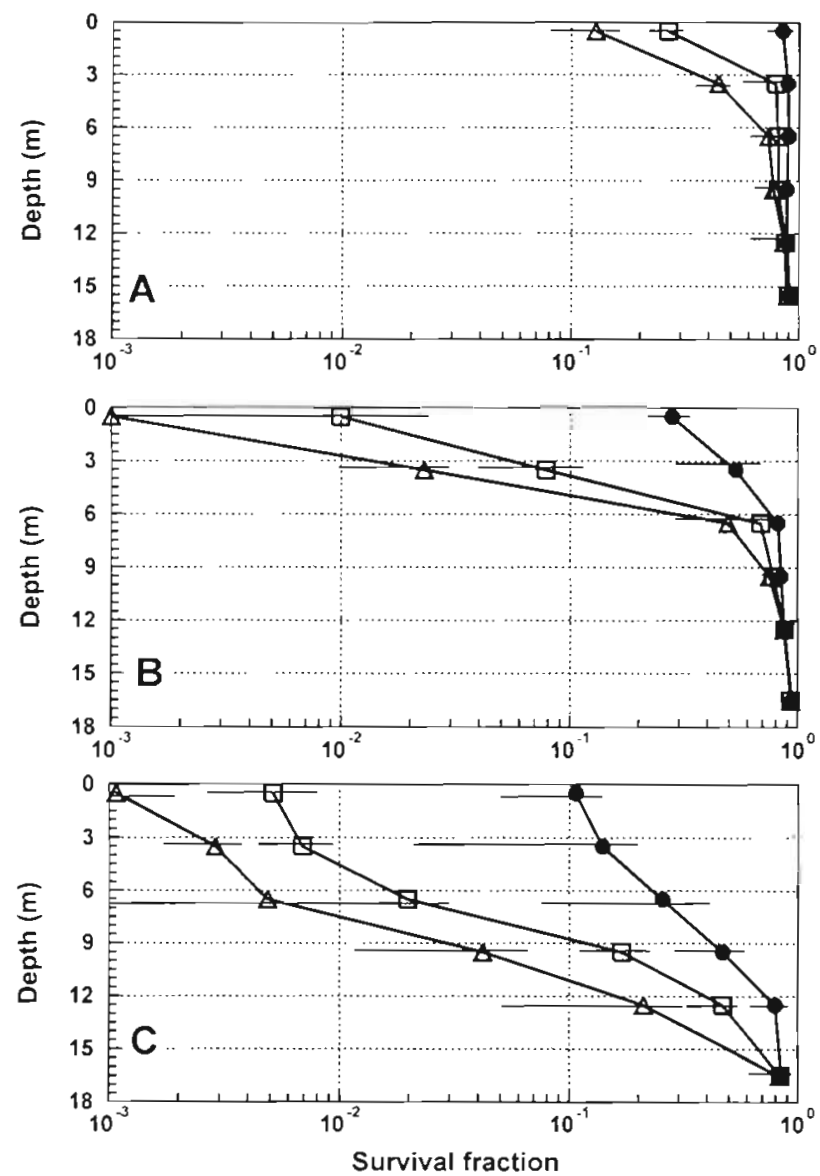

Fig. 1. Data from in situ incubations showing mean survival fractions of bacterial cells as a function of incubation depth for 3 different treatments: $(\Delta)$ quartz, which received all radiation; ( $\square$ ) Mylar which received UV-A and PAR; and (-) Plexiglas UF-3 which received only PAR. Survival fractions are based on numbers of CFU compared to control samples kept in darkness. All samples were incubated for 5 to $7 \mathrm{~h}$ during midday. Horizontal lines: 1 SD around the mean. (A) Natural bacterial assemblages incubated on December 16 and 19 , receiving a mean dose (at $320 \mathrm{~nm}$ ) of $2400 \mathrm{~J} \mathrm{~m}^{-2}$ at the sea surface. Mean PAR during the incubation period was $0.062 \mu \mathrm{E}$ $\mathrm{cm}^{-2} \mathrm{~s}^{-1}$ and mean ozone column concentration at noon was 275 Dobson Units (DU). (B) Strain of Acinetobacter sp. incubated on December 10,13, and 16, receiving a mean dose (at $320 \mathrm{~nm}$ ) of $2500 \mathrm{~J} \mathrm{~m}^{-2}$ at the sea surface. Mean PAR during the incubation period was $0.078 \mu \mathrm{E} \mathrm{cm}^{-2} \mathrm{~s}^{-1}$ and mean ozone concentration 290 DU. (C) Strain of Bacillus sp. incubated on December 10,13 , and 16 , receiving a mean dose (at $320 \mathrm{~nm}$ ) of $2600 \mathrm{~J} \mathrm{~m}^{-2}$ at the sea surface. Mean PAR during the incubation period was $0.08 \mu \mathrm{E} \mathrm{cm} \mathrm{cm}^{-2} \mathrm{~s}^{-1}$ and mean ozone concentration 290 DU

exponentially with depth, so that there was no significant inhibition detected at $9.5 \mathrm{~m}$ (Fig. 1A). The 2 bacterial isolates were much more sensitive to solar radiation than the natural bacterial assemblages, with Bacillus sp. being the more sensitive of the 2 isolates. The viability of both strains was much reduced by both UVR and PAR in surface waters, but there were no sig- nificant differences among the 3 treatments at $9.5 \mathrm{~m}$ depth for Acinetobacter sp. (Fig. 1B) and at $16.5 \mathrm{~m}$ for Bacillus sp. (Fig. 1C). UV-A radiation was responsible for a greater proportion of the loss of viability than UV-B for both bacterial strains.

In order to estimate the relationship between the spectral irradiance incident upon the experimental samples when incubated in situ and the extent to which cell viability was decreased, the attenuation of solar radiation in the upper water column was measured during all in situ deployments. Data in Fig. 2 show the attenuation of UVR and PAR in the upper $40 \mathrm{~m}$ for the days with maximal and minimal penetration of solar radiation in the water column (Fig. 2A, B, respectively). On November 19 , when phytoplankton biomass was relatively low $\left(0.6 \mathrm{mg} \mathrm{chl} \mathrm{a} \mathrm{m}^{-3}\right)$ and uniformly distributed in the upper $20 \mathrm{~m}$ of the water column, the attenuation coefficients were $0.29,0.27,0.21$, 0.096 , and $0.067 \mathrm{~m}^{-1}$ for $305,320,340$, and $380 \mathrm{~nm}$ and PAR, respectively (Fig. 2A). On December 27, the
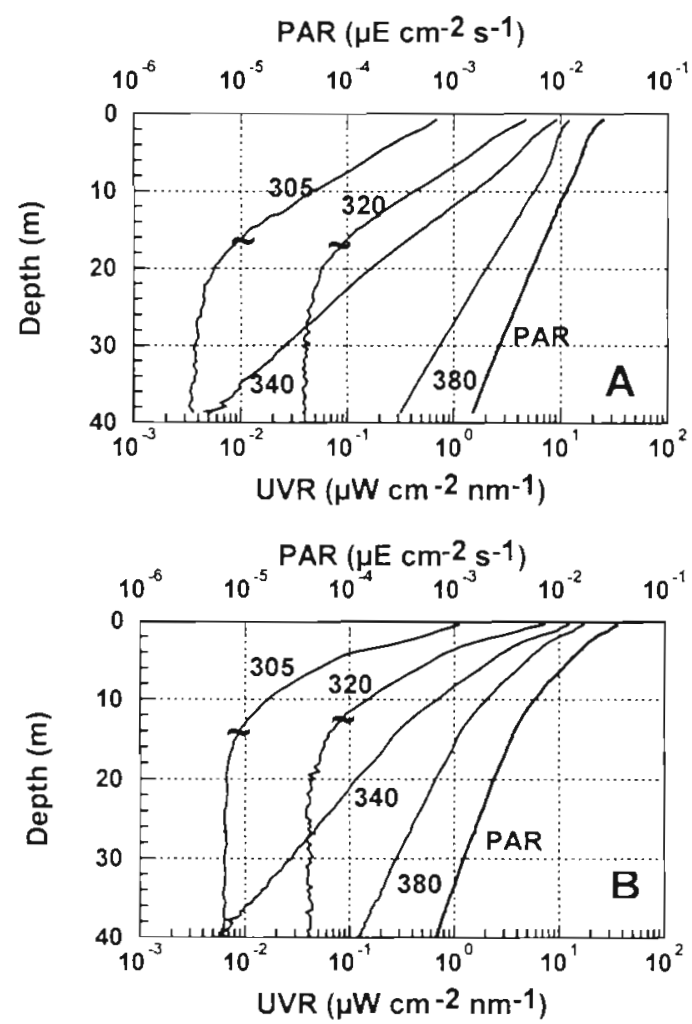

Fig. 2. Underwater radiation field as a function of depth for 4 channels $(305,320,340$, and $380 \mathrm{~nm})$ in the UVR region of the spectrum, and for PAR. 'S' shaped lines on profiles for irradiance at 305 and $320 \mathrm{~nm}$ indicate the limits of reliable detection for that sensor. (A) Data obtained on November 19, 1993, when chl a concentrations in the upper water column were all close to $0.6 \mathrm{mg} \mathrm{m}^{-3}$ (B) Data obtained on December 27, 1993, when the chl a concentrations in the upper $12 \mathrm{~m}$ of the water column were close to $3.2 \mathrm{mg} \mathrm{m}^{-3}$, and approximately $0.6 \mathrm{mg}$ $\mathrm{m}^{-3}$ below that depth 
attenuation coefficients were higher $(0.46,0.38,0.33$, 0.21 , and $0.16 \mathrm{~m}^{-1}$ for $305,320,340$, and $380 \mathrm{~nm}$ and $\mathrm{PAR}$, respectively) in the upper $12 \mathrm{~m}$ of the water column (Fig 2B) where the phytoplankton biomass was quite uniform with chl a values of $3.2 \mathrm{mg} \mathrm{chl} \mathrm{a} \mathrm{m}^{-3}$. Below $12 \mathrm{~m}$, phytoplankton biomass decreased rapidly with depth and this was reflected in much lower attenuation coefficients.

When Acinetobacter sp. and Bacillus sp. were exposed to varying irradiances in the temperaturecontrolled incubators, the results were consistent with the in situ data in that solar radiation caused a much greater loss of viability in Bacillus sp. as compared to Acinetobacter sp. (Fig. 3). UV-B, UV-A, and PAR all caused loss of viability in both bacterial strains, but for
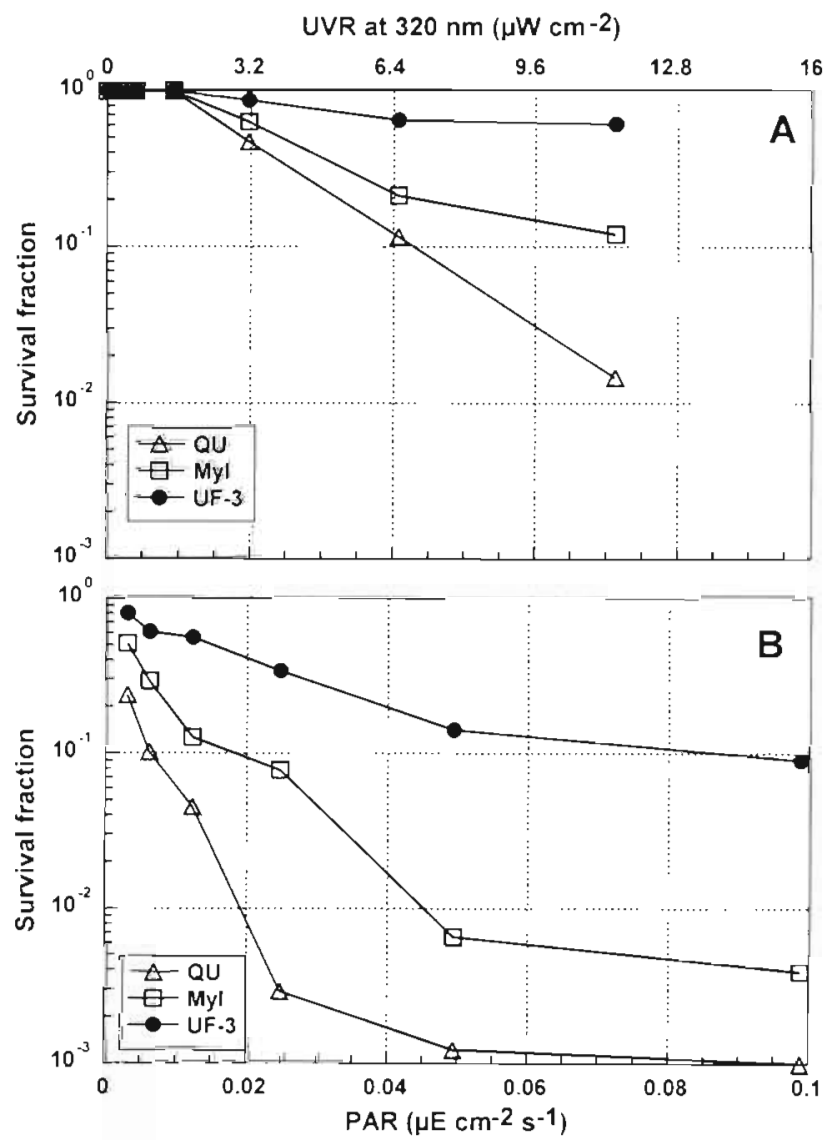

Fig. 3. Survival fraction of 2 bacterial strains as a function of the mean incident irradiation at $320 \mathrm{~nm}$ (upper abscissa) and of PAR (lower abscissa) dunng the incubation period for 3 different treatments: $(\Delta)$ quartz, which received all radiation; () Mylar, which received UV-A and PAR; and (1) Plexiglas UF-3, which received only PAR. Survival fractions are based on numbers of CFU compared to control samples kept in darkness. Ozone column concentration at noon was 285 DU. (A) Strain of Acinetobacter sp., which received a dose (at 320 $\mathrm{nm}$ ) of $1500 \mathrm{~J} \mathrm{~m}^{-2}$ for the unattenuated sample. (B) Strain of Bacillus sp., which received a dose (at $320 \mathrm{~nm}$ ) of $2800 \mathrm{~J} \mathrm{~m}^{-2}$ for the unattenuated sample
Acinetobacter sp. there was a threshold between 0.01 and $0.02 \mu \mathrm{E} \mathrm{cm} \mathrm{cm}^{-2} \mathrm{~s}^{-1}$ (corresponding to about $1.6 \mu \mathrm{W} \mathrm{cm} \mathrm{cm}^{-2}$ at $320 \mathrm{~nm}$; Fig. 3A), below which there was no loss of viability detected. No such threshold was apparent in the response by Bacillus sp., as viability was still reduced when the irradiance of PAR was approximately $0.002 \mu \mathrm{E} \mathrm{cm}^{-2} \mathrm{~s}^{-1}$ (Fig. 3B). As noted before, the effect of UV-A radiation was greater than that of UV-B radiation in causing loss of viability.

Data from the experiments designed to study the importance of the SOS system in repairing UVR damage are shown in Fig. 4. When the strains were transferred directly from laboratory conditions (see above) and ex-
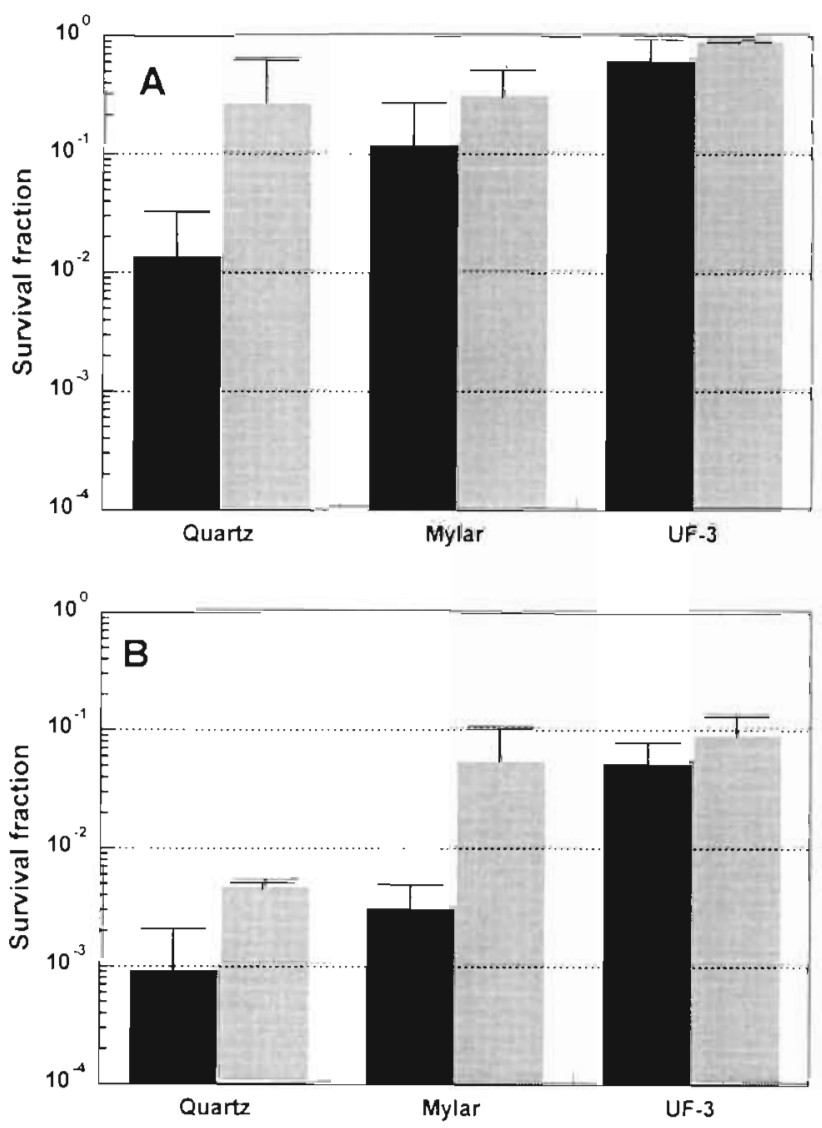

Fig. 4. Survival fraction in 2 bacterial strains before and after induction of the SOS-repair system (dark and light bars, respectively) and when exposed to 3 different radiation regimes quartz, which received all radiation; Mylar, which received UV-A and PAR; and Plexiglas UF-3, which recelved only PAR Survival fractions are based on numbers of CFU compared to control samples kept in darkness. Vertical lines on top of the bars indicate 1 SD. (A) Strain of Acinetobacter sp. incubated on December 11 and 22 for 5 to $6 \mathrm{~h}$, receiving a mean dose (at $320 \mathrm{~nm}$ ) of $2200 \mathrm{~J} \mathrm{~m}^{-2}$. Mean PAR during the incubation period was $0.08 \mu \mathrm{E} \mathrm{cm}^{-2} \mathrm{~s}^{-1}$ and mean ozone concentration $290 \mathrm{DU}$. (B) Strain of Bacillus sp. incubated on December 11,16 and 22 for 5 to $6 \mathrm{~h}$, receiving a mean dose (at $320 \mathrm{~nm}$ ) of $2400 \mathrm{~J} \mathrm{~m}^{-2}$. Mean PAR during the incubation period was $0.11 \mu \mathrm{E} \mathrm{cm}^{-2} \mathrm{~s}^{-1}$ and mean ozone concentration 295 DU 
posed to solar radiation, they showed a decrease in the survival fraction, especially in the treatments receiving all UVR. As noted previously, Bacillus sp. also showed a greater loss of viability due to high irradiance of PAR (Fig. 4B) than did Acinetobacter sp. (Fig. 4A). However, when the SOS-repair system was activated before exposure to solar radiation, the survival fraction was significantly higher in all samples receiving UVR, as compared to the samples which did not have the SOS system induced. With the SOS-repair system induced, no significant differences were observed between the quartz and Mylar treatments for Acinetobacter sp., but the viability was still less than in the samples that were not exposed to any UVR. Although Bacillus sp. showed higher viability when the SOS-repair system was induced, viability in the samples receiving UV-B was still significantly lower than when UV-B was removed by the Mylar filter (Fig. 4B).

\section{DISCUSSION}

The data presented above for natural assemblages of bacterioplankton, as well as for the 2 isolated bacterial strains, indicate that viability of bacteria in Antarctic waters may be markedly decreased by exposure to solar UVR. The impact of UV-A on cell viability was consistently greater than the impact of UV-B radiation. If the loss of cell viability is due to DNA damage resulting from UVR, one would expect that UV-B wavelengths, which overlap the absorption curve for DNA, would be the primary spectral region responsible for loss of viability. The fact that UV-A wavelengths seem to be more effective than UV-B radiation in regard to loss of cell viability suggests that damage to the DNA replication process may be via photodynamic reactions involving active oxygen species rather than by direct absorption of UVR by DNA. This interpretation would be similar to that discussed by Setlow et al. (1993) for their experimental results involving the effects of UV-A radiation on the initiation of melanomas in fish.

It should be noted that there were considerable differences in sensitivity to UVR and PAR of the 2 strains of bacteria isolated from Antarctic waters as compared to that of the natural bacterioplankton assemblages. The experimental results with the isolated strains should thus be viewed as indicative of a small fraction of the natural bacterial assemblages and cannot be extrapolated reliably to predict possible effects of enhanced UVR on the marine ecosystem. As only a few percent of marine bacteria generally will form colonies when spread onto agar plates, any bacterial isolates obtained from agar plates may not be very representative of the natural bacterial assemblages. However, results from such isolates can be useful in studying specific cellular responses to environmental stress, such as the ability to induce DNA repair processes.

Although the viability of the natural bacterial assemblages was only slightly affected by PAR, the viability of both bacterial isolates was much reduced by such visible radiation. The threshold value for inhibition of viability by PAR in Acinetobactersp. was between 0.01 and $0.02 \mu \mathrm{E} \mathrm{cm} \mathrm{cm}^{-2} \mathrm{~s}^{-1}$, which would correspond to a depth of approximately $15 \mathrm{~m}$ on a sunny day for the water column shown in Fig. 2A. For Bacillus sp., the lowest irradiance of PAR used in our experiments (approximately $0.002 \mu \mathrm{E} \mathrm{cm}^{-2} \mathrm{~s}^{-1}$, equivalent to about $0.32 \mu \mathrm{W} \mathrm{cm} \mathrm{cm}^{-2}$ at $320 \mathrm{~nm}$ ) was still inhibitory in regard to cell viability; this irradiance would correspond to a depth of about $40 \mathrm{~m}$ during the time of our experiments. These threshold irradiance values are lower than the threshold value of $3.1 \mu \mathrm{W} \mathrm{cm}^{-2}$ at $320 \mathrm{~nm}$ for inhibition of photosynthesis in Antarctic phytoplankton as reported by Helbling et al. (1994). It thus seems that viability of bacteria in Antarctic waters may be more sensitive to solar UVR than inhibition of phytoplankton primary production. Our in situ data on natural bacterioplankton assemblages are comparable with the results of Herndl et al. (1993), who reported a loss of bacterioplankton activity of about $50 \%$ in the upper $5 \mathrm{~m}$ of the water column. Inhibitory effects on bacterial metabolism by such low irradiances of solar radiation have been recognized for many years in regard to nitrifying bacteria, and have been documented in Antarctic waters by Olson (1981), who reported inhibition of the oxidation of ammonia and of nitrite by solar irradiances less than $1 \%$ of incident radiation. As the summer irradiance of solar PAR incident on most Antarctic waters is close to $0.1 \mu \mathrm{E} \mathrm{cm}^{-2} \mathrm{~s}^{-1}$, the $1 \%$ figure cited by Olson would equate to about $0.001 \mu \mathrm{E} \mathrm{cm}^{-2} \mathrm{~s}^{-1}$, which would be a little lower than the lowest irradiance used in our experiments with isolated cultures.

When the 2 strains of bacteria used in our experiments were incubated in situ, loss of viability due to solar radiation was much greater than in the natural bacterioplankton assemblages. However, when the SOS-repair system had been induced, loss of viability in Acinetobacter sp. due to UVR was comparable with the inhibition recorded for the natural bacterial assemblages; viability was also increased in Bacillus sp., but the survival fraction was still considerably lower than that for the natural assemblages. It is thus possible that the sensitivity of the 2 isolated strains to UVR was due to the fact that they had been isolated and grown in the dark in laboratory incubators (i.e. without any UVR stress) and might not have been adapted to solar radiation as were the natural assemblages of bacteria used in our experiments. 
In spite of considerable sensitivity of Antarctic bacteria to UVR, the danger of enhanced UV-B radiation resulting from stratospheric ozone depletion on the metabolic activity of bacteria in Antarctic waters would not seem to be as great as that for phytoplankton. In contrast to photoautotrophic cells, which must remain in the euphotic zone in order to maintain net growth rates, bacterial cells need not reside in surface waters to have adequate sources of organic substrates. Although viability of bacteria can be seriously impacted by solar UVR in the upper $10 \mathrm{~m}$ of the water column, the euphotic zone in Antarctic waters is generally close to 70 to $90 \mathrm{~m}$ (Tilzer et al. 1985, Helbling et al. 1994), so bacteria should not be greatly affected by UVR throughout most of the euphotic zone. Furthermore, it is apparent that bacteria also possess the capacity to acquire mechanisms to repair damage to DNA induced by UVR. Another protecting mechanism which may be operative is the synthesis of UV-absorbing compounds, which apparently do decrease cellular damage induced by UVR in many eucaryotic and procaryotic organisms (Dunlap et al. 1986, Tuveson et al. 1988, Karentz et al. 1991, Garcia-Pichel \& Castenholz 1993. Garcia-Pichel et al. 1993), but this has not yet been studied for heterotrophic bacteria in Antarctic waters. Our data suggest that the effects of solar UVR on bacterioplankton in Antarctic waters should receive further attention, especially in regard to the mechanisms of UV-B induced damage, the degree to which cells can adapt to increased fluences of UVR, and to effects of vertical mixing processes in the upper water column.

Acknowledgements. This work was supported by the U.S. National Science Foundation (OPP grant no. 92-20150). We thank all the personnel from Antarctic Support Associates at Palmer Station for their help, which made this work possible.

\section{LITERATURE CITED}

Austin B (1982) Marine microbiology. Cambridge University Press, Cambridge

Cho BC, Azam F (1990) Biogeochemical significance of bacterial biomass in the ocean's euphotic zone. Mar Ecol Prog Ser 63:253-259

Dunlap WC, Chalker BE, Oliver JK (1986) Bathymetric adaptations of reef-building corals at Davies Reef, Great Barrier Reef, Australia. III. UV-B absorbing compounds. J exp mar Biol Ecol 104:239-248

Garcia-Pichel F, Castenholz RW (1993) Occurrence of UVabsorbing, mycosporine-like compounds among cyano-

This article was submitted to the editor bacterial isolates and an estimate of their screening capacity. Appl environ Microbiol 59:163-169

Garcia-Pichel F, Wingard CE. Castenholz RW (1993) Evidence regarding the UV sunscreen role of a mycosporinelike compound in the cyanobacterium Gloeocapsa sp. Appl environ Microbiol 59:170-176

Helbling EW, Villafañe V, Ferrario M, Holm-Hansen $O$ (1992) Impact of natural ultraviolet radiation on rates of photosynthesis and on specific marine phytoplankton species. Mar Ecol Prog Ser 80:89-100

Helbling EW, Villafane V, Holm-Hansen O (1994) Effects of ultraviolet radiation on antarctic marine phytoplankton photosynthesis with particular attention to the influence of mixing. In: Weiler $\mathrm{S}$, Penhale $\mathrm{P}$ (eds) Ultraviolet radiation in Antarctica: measurements and biological effects. Antarct Res Ser 62:207-227

Herndl GJ, Müller-Niklas G, Frick J (1993) Major role of ultraviolet-B in controlling bacterioplankton growth in the surface layer of the ocean. Nature 361:717-719

Holm-Hansen O, Helbling EW, Lubin D (1993) Ultraviolet radiation in Antarctica: inhibition of primary production. Photochem Photobiol 58:567-570

Karentz D, McEuen FS, Land MC, Dunlap WC (1991) Survey of mycosporine-like amino acid compounds in Antarctic marine organisms: potential protection from ultraviolet exposure. Mar Biol 108:157-166

Little JW, Mount DW (1982) The SOS regulatory system of Escherichia coli. Cell 29:11-22

Olson RJ (1981) Differential photoinhibition of marine nitrifying bacteria: a possible mechanism for the formation of the primary nitrite maximum. J mar Res 39:227-238

Piddock LJV, Walters RN (1992) Bactericidal activities of five quinolona for Escherichia coli strains with mutations in gene encoding the SOS response or cell division. Antimicrob Agents Chemother 36:814-825

Sancar A, Sancar GB (1988) DNA repair enzymes. A Rev Biochem 57:29-67

Setlow RB, Grist E, Tompson K, Woodhead AD (1993) Wavelengths effective in induction of malignant melanoma. Proc natl Acad Sci USA 90:6666-6670

Smith RC, Prezelin BB, Baker KS, Bidigare RR, Boucher NP, Coley T, Karentz D. Macintyre S, Matlick HA, Menzies D, Ondrusek M, Man Z, Waters KJ (1992) Ozone depletion ultraviolet radiation and phytoplankton biology in Antarctic waters. Science 255:952-959

Tilzer MM, von Bodungen B, Smetacek VS (1985) Light-dependence of phytoplankton photosynthesis in the Antarctic Ocean: implications for regulating productivity. In Siegfned WR, Condy PR, Laws RM (eds) Antarctic nutrient cycles and food webs. Springer-Verlag, Berlin, p 60-69

Tuveson RW, Larson RA, Kagan J (1988) Role of cloned carotenoid genes expressed in Escherichia coli in protecting against inactivation by near UV light and specific phototoxic molecules. J Bacteriol 170:4675-4680

Weiler $S$, Penhale $P$ (eds) (1994) Ultraviolet radiation in Antarctica: measurements and biological effects. Antarct Res Ser 62

Young AR, Björn LO, Moan J, Nultsch W (eds) (1993) Environmental UV photobiology. Plenum Press, London

Manuscript first received: February 22, 1995

Revised version accepted: April 11, 1995 